\title{
GERAK TANGAN SEBAGAI ISYARAT DALAM MASYARAKAT JEPANG DAN MASYARAKAT INDONESIA
}

\author{
Maharani Patria Ratna \\ Fakultas Ilmu Budaya Universitas Diponegoro \\ Email: maharanipr_yellow@yahoo.co.id
}

\begin{abstract}
This article describes phenomenon of similarities and differences gestures which have similarities and differences in the interpretation of the meaning of Japan society and Indonesia society. In Japan society and Indonesia society, equations of motion cues with similar meaning indicating similarities mindsets. In contrast, differences in gestures with different meanings show different mindset. This paper also describes some cases phenomenon of gesture interpretation misunderstandings caused by cultural differences between speaker and listener. To learn a language, is to learn the culture contained therein
\end{abstract}

Keywords: gestures, mindsets, society, culture, phenomenon

\section{Pendahuluan}

Secara tidak sadar, sebenarnya manusia menggunakan dua jenis komunikasi dalam kehidupan sehari-hari, yakni komunikasi verbal dan komunikasi non verbal untuk mengungkapkan maksud, perasaan, dan informasi kepada orang lain. Komunikasi verbal adalah tindak komunikasi yang disampaikan melalui lisan dan melalui tulisan. Sedangkan komunikasi non verbal adalah tindak komunikasi yang dilakukan melalui gerak tubuh. Bidang penelitian komunikasi verbal adalah bahasa, yang mencakup seluruh aspek dalam pembelajaran linguistik, seperti sintaksis, semantik, morfologi, dan lain-lain. Lain halnya dengan komunikasi non verbal, komunikasi non verbal mengkaji seluruh aspek non bahasa dalam komunikasi, yang didalamnya termasuk proxemics, yakni jarak yang diambil masing-masing pihak dalam berkomunikasi; paralinguistik, yakni cara menggunakan vokal atau suara pada saat sedang berbicara; dan kinesika, yakni tindak komunikasi dengan bahasa tubuh. Kinesika dalam masyarakat awam lebih dikenal dengan sebutan bahasa tubuh atau bodi range-ji (ボディランゲージ). Nakano (1988) menyatakan bahwa mimik atau hyoujou (表情), tindakan atau shigusa (仕 草), gerak isyarat atau jesucha- (ジェスチ
ヤ一), gerak tangan atau temane (手まね) dan gerak tubuh atau miburi (身振り) adalah bersinonim. Berdasarkan variasi istilah tersebut, pada makalah ini akan digunakan istilah ''gerak isyarat', yang mengacu pada beberapa istilah di atas.

Gerak isyarat memiliki beberapa objek penelitian yang dapat dikategorikan berdasarkan anggota tubuh, diantaranya adalah temane atau teburi (手振り) yang bermakna gerak tangan, gerak kepala atau atama no hataraki (頭の働き), dan gerak kaki atau ashi no hataraki (足の働き). Secara umum, gerakan tangan adalah salah satu gerakan yang memiliki banyak variasi penggunaan dalam pembelajaran bahasa tubuh. Gerakan tangan yang sama ada kalanya memiliki persamaan makna antarmasyarakat yang berbeda. Seperti pada saat memerintahkan seseorang untuk diam, masyarakat Jepang dan masyarakat Indonesia sama-sama menggunakan isyarat dengan jari telunjuk diletakkan di depan bibir, seperti pada gambar di bawah ini.

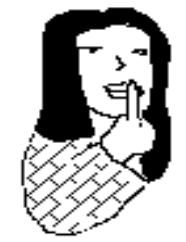




\section{Gambar 1}

Namun ada kalanya gerakan tangan yang berbeda memiliki kesamaan makna dalam suatu masyarakat. Sebagai contoh, saat menyatakan suatu hal positif dan menyatakan persetujuan dalam masyarakat Jepang dan masyarakat Indonesia. Masyarakat Jepang membentuk lingkaran dengan jari telunjuk dan jempol (gambar 2), sedangkan masyarakat Indonesia mengacungkan jempol (gambar 3).
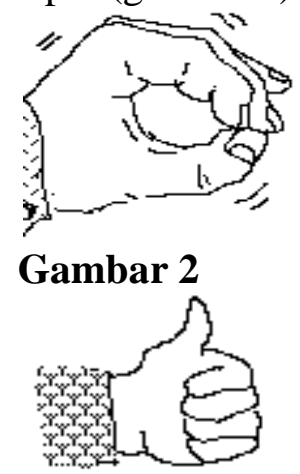

\section{Gambar 3}

Berdasarkan fenomena tersebut, penelitian ini akan mengidentifikasi lebih lanjut mengenai fenomena gerak tangan sebagai isyarat dalam masyarakat Jepang dan masyarakat Indonesia. Selain mengidentifikasi fenomena gerak isyarat, diuraikan pula latar belakang mengenai alasan penafsiran makna suatu gerak isyarat. Sebagai contoh fenomena, penelitian ini memaparkan beberapa kasus kesalahpahaman gerak isyarat yang terjadi karena kurangnya pengetahuan budaya pada suatu masyarakat tertentu.

\section{Fenomena Persamaan Gerak Isyarat Dengan Makna Yang Sama Pada Masyarakat Jepang dan Masyarakat Indonesia}

\subsection{Gerak isyarat untuk menyuruh diam seseorang}

Seperti yang telah diuraikan sebelumnya, masyarakat Jepang dan masyarakat Indonesia memiliki gerak isyarat yang sama untuk menyuruh diam seseorang. Gerakan ini dilakukan dengan jari telunjuk yang diletakkan di depan bibir (gambar 1). Gerakan ini bermakna bahwa jari telunjuk yang diletakkan di depan bibir akan menyulitkan seseorang untuk berbicara, sehingga perintah untuk diam dapat disampaikan melalui gerak isyarat ini.

\subsection{Gerak isyarat untuk memanggil Seseorang}

Untuk memanggil seseorang, masyarakat Jepang dan masyarakat Indonesia memiliki gerak isyarat yang sama. Gerak isyarat ini dilakukan dengan menelungkupkan tangan kanan dan melambaikannya ke atas dan ke bawah berulang-ulang ke arah orang yang dipanggil. Gerakan lambaian ke atas dan ke bawah yang dilakukan berulang-ulang bertujuan untuk menarik perhatian orang yang dipanggil. Dalam masyarakat Jepang, gerak isyarat yang ditunjukkan pada gambar 4 ini hanya dipakai untuk memanggil orang yang sebaya atau lebih muda. Sebaliknya, gerakan membalikan telapak tangan dan menggerakannya ke depan dan belakang dalam masyarakat Jepang digunakan untuk memanggil binatang, namun hal tersebut tidak berlaku dalam masyarakat Indonesia

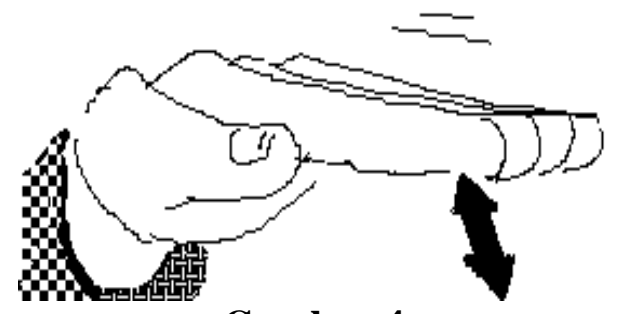

Gambar 4

\subsection{Gerak isyarat untuk menyatakan perpisahan}

Gerakan lambaian tangan yang digerakan ke kiri dan ke kanan berulangulang (gambar 5) dalam masyarakat Jepang dan masyarakat Indonesia sama-sama dipakai untuk menyatakan suatu perpisahan dan untuk menyatakan salam kepada orang lain ketika bertemu.

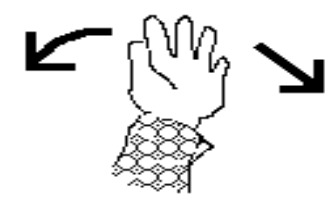




\section{Gambar 5}

\subsection{Gerak isyarat untuk menyatakan bau tidak sedap}

Ketika seseorang mencium bau yang tidak sedap, pada umumnya tanpa disadari ia akan menutup hidungnya. Masyarakat Jepang dan masyarakat Indonesia memiliki gerak isyarat yang sama untuk menyatakan terciumnya bau tidak sedap. Gerak isyarat ini dilakukan dengan menutup lubang hidung atau mengibaskan tangan di depan hidup (gambar 6). Tujuan penutupan lubang hidung tentunya bertujuan untuk menghindari terciumnya bau tak sedap, sedangkan gerakan mengibaskan tangan di depan hidung bertujuan untuk membuat angin, agar bau yang tidak sedap tidak begitu tercium.

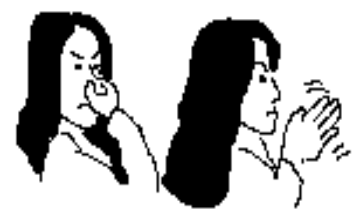

Gambar 6

\subsection{Gerak isyarat untuk menulis di udara}

Masyarakat Jepang dan masyarakat Indonesia ketika menulis sesuatu di udara, sama-sama menggunakan jari telunjuk. Contohnya di Jepang, ketika seseorang berusaha menuliskan kanji yang tidak dimengerti oleh orang lain, biasanya gambaran mengenai kanji tersebut dituliskan dengan menggambarkan kanji tersebut dengan jari telunjuk di udara atau di telapak tangan (Gambar 7). Hal ini dapat ditemui pula di Indonesia, terutama pada mahasiswa pembelajar bahasa Jepang dan China. Di Indonesia, gerakan menulis dengan telunjuk di udara atau telapak tangan biasa dilakukan untuk menggambarkan bentuk suatu objek yang tidak dimengerti lawan bicara.

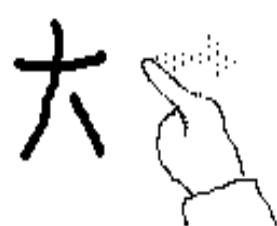

Gambar 7

\section{Fenomena Perbedaan Gerak Isyarat Pada Masyarakat Jepang dan Masyarakat Indonesia Berdasarkan Persamaan Makna}

2.1 Gerak isyarat untuk menyatakan hal yang positif

Dalam masyarakat Jepang, untuk menyatakan suatu hal yang positif dilakukan dengan membuat lingkaran dengan jari telunjuk dan jempol yang dianggap mirip dengan huruf "'O' yang merupakan huruf awal dari kata "OK' sebagai pemaknaan positif terhadap sesuatu (Gambar 2). Selain itu, gerakan isyarat seperti ini dalam bahasa Jepang dianggap melambangkan kata maru ( 丸) yang berarti lingkaran. Saat para guru di sekolah Jepang mengoreksi tes tertulis muridnya, mereka menggunakan tanda lingkaran guna menyatakan poin pada bagian yang benar.

Dalam masyarakat Indonesia, isyarat untuk menyatakan hal yang positif diisyaratkan dengan mengacungkan jempol seperti pada gambar 3. Masyarakat Indonesia memiliki sebutan lain untuk menyebut jempol, yakni ibu jari, sehingga jempol digambarkan merupakan jari yang paling baik diantara jari yang lainnya. Gerakan pada gambar 2 \& gambar 3 secara umum digunakan untuk mengisyaratkan suatu hal yang positif, namun secara khusus gerak isyarat tersebut juga dapat digunakan untuk menyatakan suatu hal yang benar, persetujuan, hal yang baik, dan lain-lain tergantung pada konteks yang menyertai. 


\subsection{Gerak Isyarat Untuk Menyatakan Hal Negatif}

Untuk menyatakan hal negatif, masyarakat Jepang dan masyarakat Indonesia memiliki gerak isyarat yang berbeda. Dalam masyarakat Jepang diisyaratkan dengan gerakan menyilangkan kedua tangan seperti pada gambar 8 . Sedangkan dalam masyarakat Indonesia, diisyaratkan dengan mengacungkan jempol terbalik seperti pada gambar 9. Kedua gerak isyarat pada gambar 8 \& gambar 9, secara umum dapat digunakan untuk mengisyaratkan berbagai hal yang negatif, salah, tidak baik, ketidaksetujuan, dan lainlain.

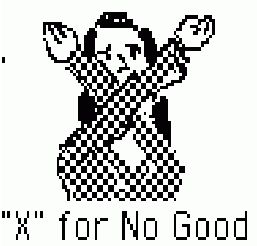

\section{Gambar 8}

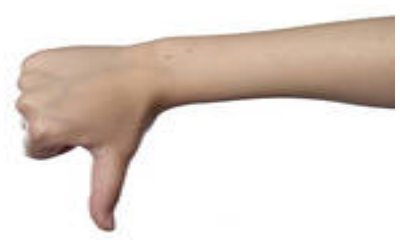

\section{Gambar 9}

\subsection{Gerak isyarat untuk menyatakan ketidaksetujuan}

Mengatakan tidak atau iie (いいえ) dalam budaya masyarakat Jepang sangat dihindari, oleh karena itu, lahirlah gerak isyarat untuk menyatakan iie. Menyatakan iie dengan gerak isyarat dianggap lebih sopan daripada secara terang-terangan mengatakan iie. Gerak isyarat untuk menyatakan iie dilakukan dengan menaruh tangan di depan wajah dengan posisi tangan jempol berada tegak lurus di depan hidung, kemudian melambaikannya ke kanan dan kiri (gambar 10). Hal ini mirip seperti gerak isyarat pada saat menyatakan bau tidak sedap. Sedangkan dalam masyarakat Indonesia, untuk menyatakan suatu ketidaksetujuan, diisyaratkan dengan gerakan yang sama untuk menyatakan perpisahan, yakni seperti pada gambar 5 dan gambar 9.

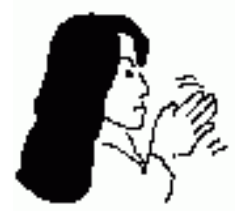

\section{Gambar 10}

\subsection{Gerak isyarat untuk menyatakan uang}

Dalam masyarakat Jepang, untuk mengisyaratkan uang dilakukan dengan gerakan membuat lingkaran dengan telunjuk dan jempol atau oyayubi to hitosashiyubi de maru o tsukuru (親指と人差指で丸を作る ). Ketika seseorang melakukan gerakan tersebut dapat berarti bahwa ia meminta tolong untuk dipinjami uang atau bahkan sedang tidak punya uang, tergantung konteks dalam dialog. Awalnya gerakan ini muncul pada zaman Edo. Pada zaman tersebut, para samurai atau ksatria Jepang beranggapan bahwa uang adalah hal yang kotor. Untuk itu, guna menghindari penyebutannya, terciptalah gerak isyarat seperti pada gambar 8 , yang memiliki gerak isyarat yang sama untuk menyatakan persetujuan. Sedangkan dalam masyarakat Indonesia, gerakan yang mengisyaratkan uang dilakukan dengan menggesekkan jari telunjuk ke jempol. Gerakan seperti ini dilakukan seperti gerakan menghitung uang pegawai bank seperti pada gambar 9 .

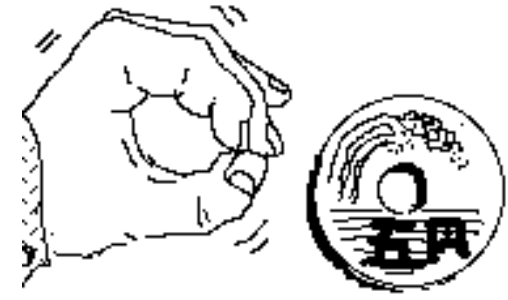

Gambar 8

\section{Gambar 9}




\subsection{Gerak Isyarat untuk}

menyatakan penunjukkan pada diri sendiri

Dalam masyarakat Jepang, untuk menunjuk diri sendiri, diisyaratkan dengan menunjuk ujung hidung sendiri (gambar 10). Penunjukkan hidung biasanya disertai dengan mimik keheranan, keterkejutan, kesenangan, tergantung pada konteks yang berlaku, sambil berkata "Aku?" atau “'Boku?' ( 僕 ). Penunjukkan hidung dilakukan karena hidung dianggap sebagai bagian tubuh yang menyatakan suatu identitas diri dan kebanggaan. Oleh karena itu terdapat idiom bahasa Jepang yang berbunyi hana ga takai (鼻が高い) yang berarti sombong. Sedangkan pada masyarakat Indonesia, penunjukkan diri sendiri dilakukan dengan menunjuk dada menggunakan telapak tangan atau telunjuk (Gambar 11). Diantara cara penunjukkan yang berbeda tersebut, gerakan menunjuk diri sendiri dengan telapak tangan dianggap lebih sopan dan bersifat formal, namun hal sebaliknya berlaku pada penunjukkan menggunakan telunjuk. Dada bagi masyarakat Indonesia dianggap sebagai anggota tubuh yang mewakili diri sendiri. Oleh karena itu, masyarakat Indonesia dalam menyatakan perasaan diri sendiri sering menunjuk pada dada. Selain itu, terdapat majas hiperbola dalam bahasa Indonesia yang berbunyi 'Belahlah Dadaku Ini'. Majas ini juga mengindikasikan bahwa jati diri orang yang sebenarnya ada di dalam dada, untuk menunjukkan apa yang benarbenar sedang dirasakan seseorang.

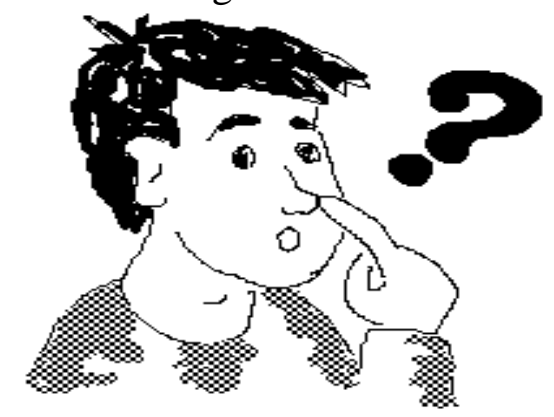

Gambar 10

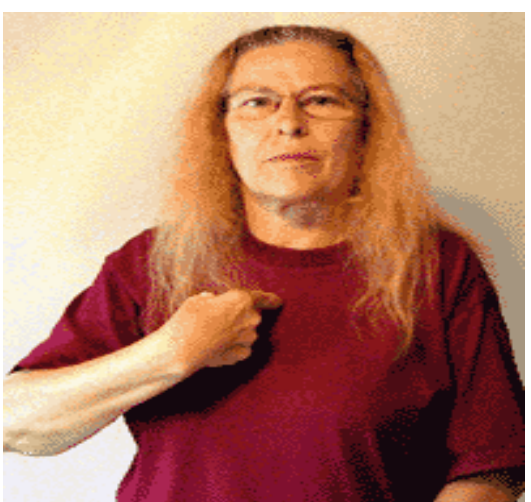

Gambar 11

\section{Analisis Kasus Kesalahpahaman Gerak Isyarat}

Berikut ini adalah beberapa contoh kasus kesalahpahaman gerak isyarat yang terjadi karena kurangnya pengetahuan mengenai gerak isyarat pada suatu masyarakat tertentu.

1. Gerak isyarat memanggil seseorang di Jepang

Orang Amerika yang sedang mengajar bahasa Inggris di Jepang, mencoba menunjuk salah satu muridnya untuk maju ke depan kelas. Orang Amerika tersebut menggunakan jari telunjuknya untuk menunjuk. Sontak hal tersebut membuat para murid kaget dan memandang sang guru dengan tatapan aneh. Fenomena tersebut menggambarkan orang Amerika yang tidak mengetahui bahwa untuk memanggil orang dalam budaya Jepang, lazimnya tidak menggunakan jari telunjuk, karena akan dianggap menantang orang yang dipanggil. Dalam budaya Jepang, gerak isyarat untuk memanggil orang Jepang adalah dengan gerak isyarat seperti pada gambar 4 .

2. Gerak isyarat untuk menyatakan hal positif di Indonesia

Seorang pelancong dari Indonesia yang sedang berkunjung ke timur tengah tengah melakukan transaksi jual beli di sebuah pasar. Setelah mendapat harga yang cocok, orang Indonesia tersebut mengacungkan jempol sebagai pertanda setuju atau menyatakan hal yang positif. 
Gerak isyarat pengacungan jempol tersebut tentu saja membuat sang pedangang tersebut kaget. Fenomena yang terjadi di atas, terjadi karena orang Indonesia tersebut tidak mengetahui bahwa di timur tengah, gerakan pengacungan jempol sangat dihindari. Hal ini dikarenakan, masyarakat timur tengah menganggap bahwa gerak isyarat tersebut memiliki makna yang kurang sopan.

3. Gerakan isyarat untuk melambangkan keramahtamahan dan kehangatan

Pada sebuah tayangan iklan televisi yang pernah ditayangkan, terdapat contoh kesalahpahaman gerak isyarat yang bernilai positif. Iklan tersebut menceritakan orang Jepang dan orang Amerika yang sedang bertemu dalam sebuah pertemuan bisnis. Orang Jepang merasa bahwa ia akan bertemu dengan orang Amerika, sehingga ia mengulurkan tangan untuk berjabat tangan sebagai ganti membungkukan badan atau ojigi (お辞儀) yang biasa ia lakukan di Jepang. Namun diluar perkiraan orang Jepang tersebut, orang Amerika merasa bahwa ia bertemu dengan orang Jepang dan ingin menunjukkan penghargaannya terhadap budaya Jepang, justru justru melakukan ojigi. Dalam iklan, Orang Jepang dan orang Amerika terlihat saling ingin menunjukkan penghargaan pada pada budaya mitra bisnis, sehingga terjadi kesalahpahaman. Sebenarnya hal ini tidak perlu terjadi jika keduanya paham mengenai konsep 'Di mana bumi dipijak, di situ langit dijunjung', Jika pertemuan itu diadakan di Jepang, maka sebaiknya orang Jepang tidak menjabat tangan orang Amerika dan tetap melakukan ojigi, namun sebaliknya ketika pertemuan itu diadakan di Amerika maka sebaiknya orang Amerika tidak membungkuk, melainkan menjabat tangan orang Jepang.

\section{Gerakan menerima barang dengan tangan} kanan dalam masyarakat Indonesia

Seorang murid pertukaran pelajar dari Jerman datang ke Indonesia. Suatu saat, ia mendapat kehormatan untuk menerima buah tangan di depan para guru dan murid lainnya sebagai ucapan selamat datang dari sekolah barunya di Indonesia. Tanpa disangka, murid Jerman tersebut menerima hadiah buah tangan yang diberikan langsung oleh kepala sekolah dengan tangan kiri. Tidak lama setelah itu, murid dari Jerman tersebut mendapat teguran dari seorang guru yang memperingatkan bahwa di Indonesia untuk menerima barang akan lebih baik dilakukan dengan dua tangan atau tangan kanan saja. Berdasarkan fenomena tersebut, dapat dipahami bahwa masyarakat Jerman tidak memiliki pemahaman yang sama dengan masyarakat Indonesia mengenai cara menerima barang dengan kedua tangan atau tangan kanan. Hal ini sekaligus membuktikan bahwa untuk berinteraksi dengan suatu masyarakat tidak cukup dengan hanya mempelajari bahasa masyarakat yang bersangkutan, namun pengetahuan mengenai budaya masyarakat tersebut juga menjadi pengetahuan yang tidak kalah penting.

5. Gerak Isyarat untuk menyatakan hal yang positif di Jepang

Tidak jauh berbeda dengan kasus nomor 2, orang Jepang yang sedang berkunjung ke Venezuela ketika menanyakan arah jalan pada orang Venezuela menunjukkan gerak isyarat OK sebagai tanda bahwa ia paham dengan penjelasan orang Venezuela tersebut. Orang Jepang tadi membuat gerak isyarat $\mathrm{OK}$, seperti pada gambar 2. Gerak isyarat tersebut justru membuat orang Venezuela tersebut cukup kaget melihatnya, karena dalam masyarakat Venezuela gerak isyarat orang Jepang tersebut berarti bahwa bahwa mitra tutur adalah penyuka sesama jenis atau homo. Gerak isyarat yang melambangkan homo tersebut juga berlaku di Turki.

\section{Gerakan Memegang kepala dengan tangan}

Banyaknya turis asing yang menetap di Bali, lalu berinteraksi dengan masyarakat setempat menjadikan interaksi diantara keduanya semakin dekat. Karena merasa dekat, beberapa turis asing terkadang mengungkapkannya dengan memegang 
kepala orang Bali. Tentu saja hal ini membuat orang Bali tersinggung. Kejadian tersebut menggambarkan suatu fenomena kesalahpahaman pemaknaan gerakan memegang kepala. Bagi turis asing, terutama yang berasal dari negara barat, hal tersebut menunjukkan keakraban antarsesama, namun bagi masyarakat Bali hal tersebut merupakan penghinaan. Karena kepala bagi masyarakat Bali dianggap merupakan hal yang harus dihormati. Tentu saja persepsi ini tidak hanya terdapat di masyarakat Bali, masyarakat Indonesia pun pada umumnya memiliki pandangan yang sama mengenai konsep kepala.

\section{Simpulan}

Berdasarkan uraian mengenai perbedaan dan persamaan gerak isyarat tangan di atas, dapat disimpulkan bahwa persamaan pemaknaan gerak isyarat tangan pada masyarakat Jepang dan Indonesia sebagian besar disebabkan oleh persamaan pola pikir diantara keduanya. Sedangkan perbedaan pemaknaan gerak isyarat tangan dipengaruhi oleh perbedaan pola pikir antara masyarakat Jepang dan Indonesia. Pengetahuan mengenai gerak isyarat tangan sebagai pengetahuan budaya dalam sebuah masyarakat adalah sangat penting untuk menghindari kesalahpahaman dalam berinteraksi.

\section{DAFTAR PUSTAKA}

Hamiru, Aqui. 2004. 70 Japanese Gestures. Tokyo: IBC Publishing

Masayuki, Sano. 1995. Ibunka Rikai no Sutorateji-. Tokyo: Taishuukan Shoten

Nakano, Michio. 1988. Bodi range-ji Jiten. Tokyo: Taishuukan Shoten.

Seltman, Robert L, 1990. Japanese Body Language. Vermont: The School for International Training

Situs Pendukung:

www.matadornetwork.com (17 Juni 2012) 